\title{
Effects of Thalidomide and rhGM-CSF on Carbohydrate Metabolism in HL-60 Acute Promyelocytic Leukemia Cell Line
}

\author{
Hakan BOYUNAGA ${ }^{1}$, Gunnur DIKMEN ${ }^{2}$, A. Ugur URAL ${ }^{3}$, Abdullah MELEKOGLU ${ }^{4}$ \\ ${ }^{1}$ Kirikkale University, Faculty of Medicine, Department of Biochemistry, Kirikkale \\ ${ }^{2}$ Hacettepe University, Faculty of Medicine, Department of Biochemistry, Ankara \\ ${ }^{3}$ Gulhane Faculty of Medicine, Department of Hematology, Ankara \\ ${ }^{4}$ Kirikkale University, Faculty of Science and Arts, Department of Biology Kirikkale, TURKEY
}

\begin{abstract}
The purpose of this study is to investigate the in vitro effect of thalidomide and rhGM-CSF on energy metabolism rate in HL-60 cell lines. HL-60 cells were incubated with radiolabelled glucose for 4 hours. Following incubation, radiolabelled $\mathrm{CO}_{2}$ was isolated and collected in specially designed scintillation vials. The other end-products of carbohydrate catabolism collected via anion-exchange chromatography were analyzed using liquid scintillation. Protein and glycogen levels for each group were also determined. The study results indicated that the use of drugs for 2-days had no significant effect when compared with aerobic and anaerobic controls. However, groups treated with the drugs for 5 days showed significant differences. It was obvious that rhGM-CSF caused HL-60 leukemia cells to use aerobic glycolytic pathway for production of energy. When thalidomide and rhGM-CSF combination therapy results were compared with untreated control cells, it was observed that glycogen consumption was decreased by $50.37 \%$, and $\mathrm{CO}_{2}$ production was increased by $94.03 \%$. When compared with those of anaerobic controls, glycogen consumption and $\mathrm{CO}_{2}$ production rates were found to be decreased by $54.01 \%$ and increased by $96.59 \%$, respectively. As a consequence, we found that those cell lines treated with combined use of Thalidomide and rhGM-CSF caused HL-60 leukemia cells to predominantly prefer aerobic glycolytic pathways for energy production.
\end{abstract}

Keywords: Thalidomide, Metabolism, rhGM-CSF, HL-60 cell line

ÖZET

HL-60 Akut Promyelositik Lösemi Hücre Kültürlerinde Thalidomide ve rhGM-CSF Kullanılmasının Karbonhidrat Metabolizmasına Etkileri

Bu çalışma, HL-60 hücre kültürlerinde in vitro olarak thalidomide ve rhGM-CSF uygulamasının enerji metabolizmasına etkilerini araştırma amacı ile yapııdı. HL-60 hücre kültürleri radyoaktif glukozla 4 saat inkübe edildi. Ardından radioaktif işaretli $\mathrm{CO}_{2}$ özel sintilasyon viallerinde toplandı, karbonhidrat katabolizmasının diğer son ürünleri ise anyon değişim kromotografisi ile ayrıldı ve sıvı sintiIasyon aracılı̆ııyla analiz edildi. Ayrıca her grubun protein ve glikojen düzeyleri ölçüldü. İki günlük ilaç kullanımı aerobik ve anaerobik kontrollerde anlamlı bir fark oluşturmazken beş günlük ilaç kullanımında anlamlı fark olduğu tespit edildi. rhGM-CSF uygulanan HL60 lösemi hücre kültürlerinin aerobik glikolitik yola kaydığı belirlendi. Thalidomide ve rhGM-CSF kombine tedavisinin sonuçları, ilaç verilmeyen aerobik kontrol grubuyla karşısştııılığında glikojen tüketiminin \%50.37 azaldığı, CO2 üretiminin ise \%94.03 oranında arttığı belirlendi. Kombine ilaç verilen grup anaerobik kontrolle karşılaştıııdığında ise, glikojen tüketiminin \%54.01 azaldığı, CO2 üretimin ise \%96.59 arttı̆̆ı belirlendi. Sonuç olarak Thalidomide ve rhGM-CSF kombine kullanııldı̆ında, HL-60 lösemi hücrelerinin enerji üretiminde esas olarak aerobik glikolitik yolu tercih ettikleri belirlendi.

Anahtar Kelimeler: Talidomit, Metabolizma, rhGM-CSF, HL-60 hücre serisi 


\section{INTRODUCTION}

Every cell including cancer cell must find out the vital substances and generate energy via metabolizing them to be able to survive and grow. ${ }^{1}$ Tumors utilize the same basic metabolic pathways as normal tissues, but some changes in a tumor's microenvironment lead to protective metabolic adaptation..$^{2-4}$ These metabolic changes may primarily appear in energy production pathways in neoplastic cells, ${ }^{5,6}$

In the presence of oxygen, the oxidative phosphorylation pathway is active instead of anaerobic glycolysis in normal cells. In the absence of oxygen, to overcome the requirements of cell metabolism, the cells tend to use anaerobic glycolytic pathway, which is a quicker way to generate energy. It is physiologically logical and commonly called the Pasteur Effect. ${ }^{7-8}$ Although hypoxia has a major potency on normal metabolic pathways, it is not the only factor influencing tumor metabolism. Tumor cells are directed to the anaerobic glycolytic pathway even in the presence of oxygen, which is actually an inefficient pathway for ATP production of each mole of available glucose. This, so called the Crabtree Effect, showed that where glucose is high concentration in medium, tumors decrease availability of oxygen. By this way the Crabtree effect gives some advantage to tumor cells. First, tumor cells spare their other endogenous fuel in the presence of abundant glucose. Second, this effect results in the maintenance of ATP production without increasing oxidative metabolism and the associated production of free radicals. In addition, the accumulation of some intermediate metabolites, such as serine, phosphoribosyl-pyrophosphate, fructose 1,6-bisphosphate, and glycerol 3-phosphate, can trigger the mitogenic events. . $^{9-11}$

Although the alterations of glucose utilization and hypoxia in tumors are complicated biochemical processes, their clinical reflections will be a cornerstone on the therapeutic approach. Therefore, the data regarding the Pasteur Effect or the Crabtree Effect on tumor cell lines may help to evaulate the success of a given treatment. ${ }^{12-13}$

Since virtually all malignancies are associated with defects in differentiation, reestablishing differentiation programs may lead to the cessation of tumorigenic self-renewal and elimination of the malignant clone. It was shown that combining cell cycle inhibitors with myeloid growth factors induces terminal differentiation of resistant myeloid leukemias. ${ }^{14}$ Thalidomide has potent antiangiogenic activity and encourages the host to resist tumor cell invasion, inhibits the ability of the tumor spread to trigger blood vessel growth, and disrupts cell cycle in lower doses..$^{15}$

This study is aimed to investigate how thalidomide and recombinant granulocyte macrophage colony stimulating factor (rh-GM-CSF) therapy for 2 and 5 days affects the energy metabolism of HL-60 acute promyelocytic leukemia cells while inducing terminal differentiation of leukemia cells.

\section{MATERIALS AND METHODS}

This study was performed with the collaboration of Kırıkkale University School of Medicine Department of Biochemistry and Clinical Biochemistry and Gulhane School of Medicine Department of Hematology.

Chemicals and Biomaterials: D-(6-C14) Glucose was purchased from Amersham Company and hexokinase and glucose-6-phosphate dehydogenase enzymes were from Boehringer. All other chemicals used were of analytical grade. HL-60 acute promyelocytic leukemia cells were provided by Memorial SloanKettering Cancer Center NY, and maintained at $37^{\circ} \mathrm{C}$ in a $5 \% \mathrm{CO}_{2}$ environment and supportive medium of RPMI 1640 supplemented by fetal calf serum 10\%,2 $\mu \mathrm{M}$ L-Glutamine, $100 \mu \mathrm{g} / \mathrm{mL}$ streptomycine and 100 $\mathrm{U} / \mathrm{ml}$ penicilline.

Thalidomide was provided from Celgene Company, Warren NJ. NewYork USA, whereas rhGM-CSF was obtained from Novartis Leucomax (molframostim) in vials of $300 \mu \mathrm{g}$. Thalidomide was dissolved in dimethyl sulfoxide (DMSO) and stored at $-20^{\circ} \mathrm{C}$ until use and diluted in culture medium with $<0.1 \%$ DMSO immediately before use.

\section{Radioactive incubation and analysis of products:} Radioactive incubation was performed by glucose in which the sixth carbon was labelled with radioactive Carbon 14, known as (D-(6-C14) Glucose. Before the incubation procedure, the HL-60 cell culture was grown to produce an adequate quantity of cells, and separated into nine parts. Two sets of three parts were treated with each of the following chemical(s): thalidomide $(50 \mu \mathrm{M})$, rh-GM-CSF $(200 \mathrm{U} / \mathrm{ml})$ and 
Table 1. Glycogen utilization and $\mathrm{CO}_{2}$ and lactate production after the use of thalidomide, rhGM-CSF and combination of both drugs for 2 and 5 days.

\begin{tabular}{|c|c|c|c|c|c|c|}
\hline \multirow[t]{2}{*}{ Groups } & \multirow{2}{*}{ 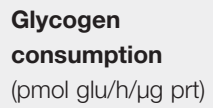 } & \multicolumn{3}{|c|}{$\begin{array}{l}\text { Labelled End-products } \\
\text { (pmol glu/h/ } / \mathrm{g} \text { prt) }\end{array}$} & \multicolumn{2}{|c|}{$\begin{array}{l}\text { Total End-products } \\
\text { (pmol glu/h/ } / \mathrm{g} \text { prt) }\end{array}$} \\
\hline & & $\overline{\mathrm{CO}_{2} \%}$ & Lactate & $\mathrm{CO}_{2}$ & $\mathrm{CO}_{2}$ & Lactate \\
\hline $\begin{array}{l}\text { Aerobic-Leucocyte } \\
\text { culture }\end{array}$ & $1026 \pm 27$ & $51,79 \pm 9.7$ & $6,47 \pm 1.4$ & 88,90 & $3522,16 \pm 361$ & $439,97 \pm 57.6$ \\
\hline $\begin{array}{l}\text { Anaerobic-Leucocyte } \\
\text { culture }\end{array}$ & $1562 \pm 68$ & $9,26 \pm 2.4$ & $83,59 \pm 12$ & 9,98 & $169,99 \pm 36$ & $1533,67 \pm 73.9$ \\
\hline Aerobic HL-Control & $2660 \pm 93$ & $5,34 \pm 1.2$ & $81,35 \pm 9.8$ & 6,16 & $172,72 \pm 17.6$ & $2631,21 \pm 68.5$ \\
\hline Anaerobic HL-Control & $2870 \pm 152$ & $3,71 \pm 3.2$ & $104,78 \pm 23.6$ & 3,42 & $101,02 \pm 42$ & $2853,16 \pm 84.8$ \\
\hline HL-2 days Thalidomide & $2580 \pm 221$ & $4,38 \pm 0.73$ & $80,39 \pm 11.2$ & 5,17 & $139,30 \pm 8.69$ & $2556,78 \pm 46.9$ \\
\hline HL-2 days GM-CSF & $2870 \pm 180$ & $3,89 \pm 1.3$ & $88,61 \pm 5.8$ & 4,21 & $25,24 \pm 4.72$ & $2849,13 \pm 92.7$ \\
\hline $\begin{array}{l}\text { HL-2 days Thalidomide } \\
\text { +GM-CSF }\end{array}$ & $2360 \pm 373$ & $4,47 \pm 0.91$ & $71,03 \pm 5.74$ & 5,92 & $146,98 \pm 8.75$ & $2335,50 \pm 204.5$ \\
\hline HL-5 days-Thalidomide & $1520 \pm 99$ & $33,95 \pm 2.86$ & $43,61 \pm 6.31$ & 43,77 & $1047,41 \pm 76.92$ & $1345,43 \pm 63.21$ \\
\hline HL- 5 days GM-CSF & $2150 \pm 239$ & $19,66 \pm 3.87$ & $67,48 \pm 8.75$ & 22,56 & $597,39 \pm 13.7$ & $2050,44 \pm 129.6$ \\
\hline $\begin{array}{l}\text { HL- } 5 \text { days Thalidomide } \\
+ \text { GM-CSF }\end{array}$ & $1320 \pm 51$ & $46,18 \pm 14.6$ & $28,37 \pm 8.92$ & 61,95 & $1690,28 \pm 28.5$ & $1038,29 \pm 84.8$ \\
\hline
\end{tabular}

thalidomide $(50 \mu \mathrm{M})+$ rh-GM-CSF $(200 \mathrm{U} / \mathrm{ml})$ combination. They were given respectively to first set for two days and another set for five days. One of the remaining three parts was the aerobic control group, the second was for the anaerobic control group after KCN (Potassium cyanide) addition, and the last part was used to determine the initial glycogen and protein levels found in the cells.

Measurements were performed in seven cell cultures in every groups. All prepared cell cultures were incubated with radiolabelled glucose for 4 hours in a specially designed chamber at $37^{\circ} \mathrm{C}$. Incubated cell cultures catabolized externally available radioactive glucose through glycolysis converting it into products which include lactate, acetate and pyruvate. Following incubation, the generated radioactive $\mathrm{CO}_{2}$ was collected in scintillation vials via nitrogen gas. After that radioactive $\mathrm{CO}_{2}$ was measured in gamma counter and results were calculated. Then, the content was separated as supernatant layer and pellets.
By using the supernatant layer, the end-products of glycolysis (lactate, acetate and pyruvate) were collected in scintillation vials by anion-exchange chromatography, and were analyzed using standard graphics in Microsoft Excel.

In the pellets, the protein content was determined by the modified Lowry Method ${ }^{16}$ and glycogen content by Hassid and Abraham's Enzymatic Method. ${ }^{17}$ Glucose concentrations in the supernatant layer were measured enzymatically by a glucose oxidase method. ${ }^{18}$ Glycogen consumption and $\mathrm{CO}_{2}$ production for each gram of protein were calculated by using the data obtained from the measurement of glycogen and protein found in the pellets.

Statistical Analyses: Statistical analysis of the data was done with 9.0 SPSS Package programme for computer. Kruskal-Wallis and Mann Wittney U tests were used for the difference between groups. p < 0.05 was assumed to be significant. 


\section{RESULTS}

In our study, both the glycogen consumption and production of $\mathrm{CO}_{2}$ and lactate were assessed in HL-60 acute promyelocytic leukemia cells that were under thalidomide $(50 \mu \mathrm{M})$, rhGM-CSF $(200 \mathrm{U} / \mathrm{ml})$ and thalidomide + rh-GM-CSF treatment for 2 and 5 days (Table 1).

When glucose-C14 was utilized by leucocyte cells in aerobic conditions, the level of $\mathrm{CO}_{2}$ was found $88.9 \%$ through the measurement of radioactive labelled end-products. This level decreased to $6.1 \%$ and meanwhile the utilization of stored glycogen (2660 versus $1027 \mathrm{pmol}$ glucose $/ \mathrm{h} / \mu \mathrm{g}$ protein) and production of lactate ( 81.35 versus $6.47 \mathrm{pmol} \mathrm{glu} / \mathrm{h} / \mathrm{\mu g} \mathrm{prt}$ ) increased in HL-60 leucemic cell culture inspite of presence of oxygen. Anaerobic glycolysis was also determined to be more predominant in both leucocyte cell culture and HL-60 cells when KCN was added to provide anaerobic conditions (Table 1).

When untreated HL-60 cell culture was compared with the cells that were treated with the drugs for 2 days, the difference was not significant in terms of glycogen consumption and production of $\mathrm{CO}_{2}$ and lactate ( $p>0.05)$. But interestingly, the difference became more remarkable when the untreated cells were compared with the cells treated with drugs for 5 days (glycogen consumption, $\mathrm{p}=0.002$; production of $\mathrm{CO}_{2}$ and lactate, $\left.\mathrm{p}=0.018\right)$ (Table 1).

In the case of drug use, combination therapy was observed as more efficient than single drug therapy (glycogen consumption, $\mathrm{p}=0.0003$; production of $\mathrm{CO}_{2}$ and lactate, $\mathrm{p}=0.0003$ ) The combination of Thalidomide and rh-GM-CSF for 2 days caused the $\mathrm{CO}_{2}$ levels to reach the rate close to the level found in the aerobic HL-60 controls. Moreover, when combination therapy were used for 5 days, the $\mathrm{CO}_{2}$ levels increased by several orders of baseline level.

However, in the cells treated with only rh-GM-CSF for 2 or 5 days, the most interesting result was the increase in lactate production and the decrease in $\mathrm{CO}_{2}$ production when compared with Thalidomide $(\mathrm{p}=0.0003)$ or combination of these drugs $(\mathrm{p}=$ $0.0003)$.

\section{DISCUSSION}

Cancer cells often exploit different metabolic pathways as compared with those used by normal cells.
Oxygen level and nutrient concentration are normally the major core factors in the exact metabolic pathway. The decreasing tissue oxygenation converts the metabolism of normal or cancer cells from aerobic pathway into anaerobic glycolysis. This condition, called the Pasteur Effect, can accelerate the consumption of glycogen and lipid stores. Warburg first reported in 1930 that cancer cells possessed anaerobic glycolysis in high degree than expected. In the Crabtree Effect, observed in cancer cells, substrate concentrations become more determining factor in the selection of the metabolic pathway; so the nutritionally adequate substrates direct the cancer cell to anaerobic glycolysis. In this metabolic process, one mole glucose breaks into lactate eventually and the net gain would be 2 moles of ATP. The main advantage of anaerobic glycolysis is to obtain ATP at a faster rate through a simpler process. ${ }^{4}$ However, when resources become scarce, aerobic pathway, being about 18-19 times more efficient than anaerobic pathway, becomes the principal choice for energy production, even though it is a more complicated process and takes longer. By this way, tumor itself slows down the metabolism and the rate of cellular division. At this point, recent studies focused on metabolic switch of the nature of cancer cells and on their clinical relevance as therapeutic target. ${ }^{19-20}$

Our study plainly revealed the decreasing level of $\mathrm{CO}_{2}$ in HL-60 leucemic cells in spite of the presence of the oxygen. These results substantially indicated that leukemic cells used anaerobic glycolytic pathway primarily.

The ratios of radiolabelled glucose catabolized into $\mathrm{CO}_{2}$ or lactate were compared after challenge of HL60 leukemic cells by two different drugs for 2 and 5 days. Data obtained after a 2-day- drug challenge showed that there was no difference between the treatment groups. On the contrary, groups treated for 5 days with the different drugs showed significant differences from both the anaerobic and aerobic situations.

In the HL-60 cell cultures under aerobic conditions, glycogen utilization was $2660 \mathrm{pmol}$ glucose $/ \mathrm{h} / \mu \mathrm{g}$ protein and $\mathrm{CO}_{2}$ production was $6.16 \%$ of total end products. In the group challenged with rhGM-CSF given for 5 days, glycogen utilization decreased to $2150 \mathrm{pmol}$ glucose $/ \mathrm{h} / \mathrm{\mu g}$ protein, with the increase of 
$\mathrm{CO}_{2}$ production up to $22.56 \%$. These results indicate that HL-60 leukemic cell cultures were metabolised predominantly via aerobic glycolysis in the presence of rh-GM-CSF when compared with aerobic controls.

In the case of thalidomide use for 5 days, glycogen utilization was found depleted by $42.8 \%$, but $\mathrm{CO}_{2}$ production increased by $89.8 \%$ in the HL-60 leukemic cell cultures compared with those of the aerobic controls. This suggests that thalidomide directs HL60 leukemic cell cultures into aerobic glycolysis more effectively than rh-GM-CSF does.

When the results of drug-free aerobic controls were compared to those of the thalidomide and rh-GMCSF combination group, glycogen consumption and $\mathrm{CO}_{2}$ production were lowered by $50.3 \%$ and increased by $94.0 \%$, respectively. Combining thalidomide treatment with the rh-GM-CSF also leads cell culture lines to metabolize to a significant extent by aerobic glycolysis.

It is evident that aerobic glycolysis is dominant in normal leukocytes. ${ }^{4-6}$ However, we determined that anerobic glycolysis was the dominant energy production method in HL-60 leukemic cell cultures. According to our results, thalidomide, at cell cycle inhibition doses, rh-GM-CSF, and a combination of both drugs were forcing the HL-60 cells into aerobic glycolysis. Then, we investigated how these drugs changed energy metabolism of HL-60 leukemic cells, transforming into aerobic glycolysis. The differentiating effect of this combination may relate to the fact that thalidomide induced cell cycle arrest occurs at the G1 phase in the mitotic cycle. Our data suggest that rh-GM-CSF in combination with the thalidomide, cell cycle inhibitor, acts synergistically with respect to tumor cell differentiation. Induction of terminal differentiation by the combination of cell cycle inhibitors and the growth factors has been demonstrated to have potent anti-leukemic activity, and may be clinically useful in treating this incurable disease. This conclusion suggests that, detailed investigations should be initiated to study whether this effect might be due to enzymatic activity at the control points of glycolysis, or to the other factors as yet unknown.

\section{REFERENCES}

1. Fischer CP, Bode BP, Souba WW. Adaptive alterations in cellular metabolism with malignant transformation. Ann Surg 227: 627-34, 1998.

2. Semenza GL. Tumor metabolism: cancer cells give and take lactate. J Clin Invest 118: 3835-3837, 2008.

3. Newsholme EA, Board M. Application of metaboliccontrol logic to fuel utilization and its significance in tumor cells. Adv Enzyme Regul 31: 225-246, 1991.

4. DeBerardinis RJ. Is cancer a disease of abnormal cellular metabolism? New angles on an old idea. Genet Med 10: 767-777, 2008.

5. Zu XL, Guppy M. Cancer metabolism: facts, fantasy, and fiction. Biochem. and Biophysic Res Comm 313: 459-465, 2004.

6. DeBerardinis RJ, Lum JJ, Hatzivassiliou G, et al. The biology of cancer: metabolic reprogramming fuels cell growth and proliferation. Cell Metab 7:11-20, 2008.

7. Tiffany N. Seagroves, 1 Heather $E$ et al Transcription Factor HIF-1 Is a Necessary Mediator of the Pasteur Effect in Mammalian Cells. Molecular and Cellular Biology 21: 3436-3444, 2001.

8. Jones RG, Thompson CB. Tumor suppressors and cell metabolism: a recipe for cancer growth. Genes Dev. Mar; 23: 537-548, 2009

9. Mayevsky A. Mitochondrial function and energy metabolism in cancer cells: Past overview and future perspectives. Mitochondrion 9: 165-179, 2009.

10. Mazurek S, Eigenbrodt E. The tumor metabolome. Anticancer Res 23: 1149-1154, 2003.

11. Melo RF, Stevan FR, Campello AP, et al. Occurrence of the Crabtree effect in HeLa cells. Cell Biochem Func 16: 99-105, 1998.

12. Hsu PP, Sabatini DM. Cancer cell metabolism: Warburg and beyond. Cell 5;134: 703-707, 2008.

13. Vander Heiden MG, Cantley LC, Thompson CB. Understanding the Warburg effect: The metabolic requirements of cell proliferation. Science. 324: 102933, 2009.

14. Holtz M, Forman SJ, Bhatia R. Growth factor stimulation reduces residual quiescent chronic myelogenous leukemia progenitors remaining after imatinib treatment. Cancer Res 67: 1113-1120, 2007.

15. Di Raimondo F, Palumbo GA, Molica S, et al. Angiogenesis in chronic myeloproliferative diseases. Acta Haematol 106: 177-183, 2001.

16. Lowry $\mathrm{OH}$, Rosbrough NJ, Farr A, et al. J Biol Chem 193: 265, 1951.

17. Hassid WZ, Abraham S. Chemical procedures for analysis of polysaccharides. Methods Enzymol 3-34, 1957. 
18. Bentley R. The Enzymes. P. Boyer, H. Lardy, and K. Myrback, 2st edition. New York Academic Press, 1963: 567.

19. Pavlides S, Whitaker-Menezes D, Castello-Cros R, et al. The reverse Warburg effect: Aerobic glycolysis in cancer associated fibroblasts and the tumor stroma. Cell Cycle 8: 3984-4001, 2009.

20. Sattler UG, Hirschhaeusera F, Mueller-Klieser WF. Manipulation of Glycolysis in Malignant Tumors: Fantasy or Therapy. Curr Med Chem 17: 96-108, 2010.

\section{Correspondence}

Dr. Hakan BOYUNAĞA

Kırıkkale Üniversitesi Tıp Fakültesi

Biyokimya Anabilim Dalı

71100 Kırıkkale / TURKEY

Tel: (+90.318) 2252485

Fax: (+90.318) 2252819

e-mail: hboyunaga2000@yahoo.com 